\title{
Doubting Divine Justice and Human Knowledge: Qohelet's Cultural Dialectics
}

Julius Guttmann was explicitly reluctant to begin his narrative of Jewish philosophical thought with Qohelet. He argued that this biblical book, which is also known as Ecclesiastes, may document the first known encounter between Jewish literature and Greek philosophy, but that it was a failed encounter, since the biblical author proved unable to understand philosophical ways of thought; worse, he even maintained his utterly "un-Greek" disrespect for the human cognitive faculties, denying their power, nobility, and efficiency. ${ }^{1}$

Our conception of antique intellectual culture has evolved, and we are more likely to acknowledge that cognitive pessimism and the sceptical quest are as much a part of Greek thought as the Platonic and Aristotelian systems. Qohelet has often been represented in analogy with the Greek Sceptics, ${ }^{2}$ and Charles Whitley even sensed this dimension in the author's moniker: if Qohelet "is to be represented by one term in English, perhaps 'The Sceptic' would have some measure of adequacy."3 As I will argue in this chapter, Qohelet does indeed stand on the threshold of Jewish philosophising, and of Jewish scepticism in particular, and there are good reasons to locate him inside rather than outside of the doorway. What I will undertake here is a reappraisal of the book's dialectic quest based on a review of its reception ${ }^{4}$ and a new hypothesis about its structure and date. ${ }^{5}$ By "dialectics," I mean the procedure of explaining a text on the basis of its unresolved inner contradictions. For example, Hans-Georg Gadamer's dialectical ethics reflect the tension between the immanent "other" and the transcendent "good-beyond-being” in opposition to ethi-

1 Julius Guttmann, Die Philosophie des Judentums (Munich: Ernst Reinhardt, 1933), 27: "Die ebenso ungriechische Verwerfung der Erkenntnis, das Wort, daß Mehrung der Erkenntnis Mehrung des Schmerzes ist."

2 Martin Alfred Klopfenstein, "Die Skepsis des Qohelet," Theologische Zeitschrift 28 (1972): 97-109.

3 Charles F. Whitley, Kohelet: His Language and Thought (Berlin: De Gruyter, 1979), 6.

4 I have used the overviews by Ludger Schwienhorst-Schönberger, "Kohelet: Stand und Perspektiven der Forschung," in Das Buch Kohelet: Studien zur Struktur, Geschichte, Rezeption und Theologie, ed. Ludger Schwienhorst-Schönberger (Berlin: De Gruyter, 1997), 5-38; and Jean-Jacques Lavoie, “Où en sont les études sur le livre de Qohélet?" Laval théologique et philosophique 69, no. 1 (2013): 95-133; Jean-Jacques Lavoie, “Où en sont les études sur le livre de Qohélet (2012-2018)?” Studies in Religion 48,1 (2019): 40-76.

5 The present article develops ideas that were exchanged during the dialectical evening held at the Maimonides Centre for Advanced Studies in Hamburg on 16 February 2016, when the two theses presented below were respectively defended by Reuven Kiperwasser (who at that was time was affiliated with Humboldt University of Berlin) and myself.

Ә Open Access. (c) 2021 Carsten L. Wilke, published by De Gruyter. (c) BY-NC-ND This work is licensed under the Creative Commons Attribution-NonCommercial-NoDerivatives 4.0 License.

https://doi.org/10.1515/9783110671483-002 
cal reasoning founded on one essential principle, such as divine lawgiving or the self-sufficient human subject. ${ }^{6}$

As has often been remarked, Qohelet diverges from Jewish tradition through its generic and depersonalised conception of the divine, which acts through deterministic forces such as time, fortune, and fate. He never mentions the Israelite God by name, nor does his book refer to divine law, the Torah, the ideas of creation, revelation, redemption, or other dimensions of historical religion. His view of cultic religion, expressed in 4:17-5:7, is cautious at best, and ethical religion is discarded outright.

Qohelet also, however, diverges from what we might associate with the Greek ideal of autonomous human knowledge. Man cannot know anything for certain, nor can he influence the world through his activity. As a conclusion, the author recommends that one suspend the quest for knowledge, power, and perfection and instead enjoy life without any wish to understand, dominate, or improve it. This quintessential (im)moral conclusion is reiterated in the body of the text on seven (or rather, as we will see below, ten) occasions. The very end of the text at 12:1-8, 12-14, however, is a chapter on theistic morals.

In sum, while arguably marking the start of a controversy between biblical theism and Greek science, the book expresses ideas that are strongly at variance with both. As James L. Crenshaw succinctly put it: "The author of Ecclesiastes lacked trust in either God or knowledge. For him nothing proved that God looked on creatures with favor, and the entire enterprise of wisdom had become bankrupt."7 Our dialectic reading will have to address one basic observation-namely the presence of multiple contradictions in Qohelet's thought-which, with appropriate contextualisation, will lead us to disagreements both between eastern Mediterranean wisdom traditions and within them.

\section{Harmonistic, Agonistic, and Dialectical Approaches}

As a deliberately sceptical text, Qohelet is a model case for the possible strategies we can use to deal with internal contradiction, which the ancient rabbis already considered to be the major crux of the book. ${ }^{8}$ One strategy proceeds by logical de-

6 Lauren Swayne Barthold, Gadamer's Dialectical Hermeneutics (Lanham, MD: Lexington Books, 2010), 127.

7 James L. Crenshaw, Old Testament Wisdom: An Introduction, 3rd ed. (Louisville, KY: Westminster John Knox Press, 2010), 127.

8 b. Šabb. 30b: "His words contradict one another"; compare Abraham ibn Ezra on Eccl 7:3: "In one place it may say something and in another the exact opposite is said." Sefer Qohelet: im Perushei ibn Ezra, edited by Mordechai Shaul Goodman (Jerusalem: Mosad Ha-Rav Kook, 2012). On the Talmudic quotation, see below. 
duction, either fitting the author's thought into a coherent norm or imagining a harmonic balance of opposites. For historical-critical scholars, only a single stroke of the pen was necessary to dismiss the pietistic conclusion as a conformist gloss and to keep a more or less coherent text built around the hedonistic ethics that are made explicit in its main part. On the other side, theologians have often felt obliged, following their religious convictions and duties, to explain away the central parts of the book or to diminish their relevance. Crenshaw, for instance, finds Qohelet's insistent commendation of earthly pleasure to be "empty" of meaning and does not believe that the author seriously intended to promote it. ${ }^{9}$ A good example of a harmonistic reading is given by Alexander A. Fischer, who in 1997 argued that Qohelet could have been both a sceptical philosopher and a Jewish sage:

Indeed, both issues, scepticism and the fear of God, are vital to our understanding of Qohelet's teachings. While attempts have repeatedly been made to pit the one against the other and to thereby reduce the book to a one-way interpretation, we will be sure to show that the fear of God and scepticism go together in this work and that they depend on one another. ${ }^{10}$

From a modern theological perspective, it may not be much of an issue whether we believe in or deny divine providence, but classical exegesis did not treat this point with the same nonchalance. Both the rabbis and the Church Fathers had strong feelings about the contradiction between ethical attitudes that would follow from Qohelet's calls to enjoy a meaningless life while simultaneously fearing an incomprehensible God. ${ }^{11}$ In their approach, which we may call agonistic, the Book of Qohelet was interpreted as a debate in which an impious sceptic voices his objections to faith and is finally vanquished by a pious opponent. In the thirteenth century, Menahem ha-Meiri wrote that Qohelet "mentions in a number of places views that contradict fundamental beliefs such as reward and punishment and God's providence in his world; but he mentions these views so as to use knowledge to search for the correct path."12 The great majority of Qohelet's speculative propositions could thus be explained away as counter-truths concocted by the unruly antagonist, the conclusion in chapter 12 being the only straightforward expression of the book's true message. Following this tradition, later Jewish commentators read Qohelet as a dialectical controversy between the good and evil impulses. ${ }^{13}$ Modern Christian

9 Crenshaw, Old Testament Wisdom, 138-40.

10 Alexander A. Fischer, Skepsis oder Furcht Gottes? Studien zur Komposition und Theologie des Buches Kohelet (Berlin: De Gruyter, 1997), 1.

11 For a survey of patristic interpretations, see Elisabeth Birnbaum, "Qohelet," Reallexikon für Antike und Christentum 28 (2017): 523-36.

12 Menachem ha-Meiri, Perush 'al Sefer Mishlei, ed. Menachem Mendel Zahav (Jerusalem: Otsar ha-Poskim, 1969), on Prov 1:1.

13 See the interpretation of Eccl 9:7-10 in Joseph Albo, Sefer ha-'Ikkarim, 4.28, developed in Menasseh ben Israel, De la fragilité humaine et de l'inclination de l'homme au péché, trans. Henry Méchoulan (Paris: Éditions du Cerf, 1996), 143-44. 
scholars since Johann Gottfried Herder have likewise assumed a clash between various worldviews on Qohelet's pages, possibly in the form of an internal dialogue. In 1875, Franz Julius Delitzsch wrote: "One might therefore call the Book of Koheleth, 'The Song of the Fear of God,' rather than, as H. Heine does, 'The Song of Scepticism;' for however great the sorrow of the world which is therein expressed, the religious conviction of the author remains in undiminished strength." 14 At the turn of the twentieth century, with the then-fashionable search for various redactional layers, Paul Haupt assumed that an Epicurean Sadducee and a Stoic Pharisee successively intervened in the redaction of the text, ${ }^{15}$ while Arthur Lukyn Williams read it as a dialogue between a hakam and a hasid. ${ }^{16}$ In all these constructions, the text's final voice recommending the fear of God overrules the cheerful commendations that the book expresses elsewhere. Some dialogue constructions have also been proposed in recent years, ${ }^{17}$ but twentieth-century scholarship has generally preferred to discard the unwelcome passages of the text as "glosses" or "quotations." 18

The third and last approach is dialectical: it chooses to state Qohelet's contradictions as strongly as can be and to leave them unresolved. As a revealing example, allow me to quote a forgotten booklet by an Israeli author, Asher Sakal, who in 1959 expressed this perceived opposition with particular emphasis. For Qohelet, "God is an omnipotent entity that acts arbitrarily, uncontained by any legal order. In his world, being righteous does not help, and being evil does not harm, since God could not care less about a man's good or evil deeds.” All Jewish exegesis, Sakal claims, was written in order to fit this provocation into the norms of dogmatic biblical theology. However, all of these efforts have been futile, and Qohelet's words against God's providence and justice, as well as against man's moral nobility, can in no way be reconciled with the understanding that Jewish tradition was used to giving them. ${ }^{19}$ As James Alfred Loader argued in his Polar Structures in the Book of

14 Franz Julius Delitzsch, "Einleitung das Buch Koheleth," in Biblischer Commentar über das Alte Testament. Vierter Theil: Poetische Bücher. Vierter Band: Hoheslied und Koheleth (Leipzig: Dörffling und Franke, 1875), 185-97, here 190; translation in Franz Julius Delitzsch, Commentary on the Song of Songs and Ecclesiastes, trans. M. G. Easton (Edinburgh: T\&T Clark, 1891), 183. Delitzsch misquotes Heinrich Heine, who in 1854 referred to Job, not Qohelet, as the "Canticles of Scepticism." See Friedrich Ellermeier, "Randbemerkung zur Kunst des Zitierens: Welches Buch der Bibel nannte Heinrich Heine ‘das Hohelied der Skepsis'?” Zeitschrift für die alttestamentliche Wissenschaft 77, no. 1 (1965): 93-94.

15 Paul Haupt, trans., The Book of Ecclesiastes (Baltimore: Johns Hopkins University Press, 1905), 2-4.

16 Arthur Lukyn Williams, trans., Ecclesiastes in the Revised Version with Introduction and Notes (Cambridge: Cambridge University Press, 1922), 56-57.

17 T. A. Perry, Dialogues with Kohelet: The Book of Ecclesiastes (University Park: Pennsylvania State University Press, 1993).

18 For the latter approach, see Robert Gordis, Kohelet-The Man and His World: A Study of Ecclesiastes, 3rd augmented ed. (New York: Schocken Books, 1968).

19 Asher Sakal, Sefer Qohelet: Shenei panim, peshuto shel miqra mi-zeh vehashqafat hakhmei Yisra'el mi-zeh (Holon: A. Sakal, 1959), 10-11. 
Qohelet (1979), we should also abstain from minimising the book's inner contradictions, but should rather try to understand them as elements of a systematically selfcontradictory kind of thought. ${ }^{20}$

Competition between these options for meeting Qohelet's ideological challenge runs throughout the entire history of exegesis. For modern critics, the problem is also linked to different possible means of contextualisation. In sociological terms, we are dealing with a "multi-cleavage" situation, in which the logical problem of intratextual conflict overlaps with sociocultural contradictions that may ultimately be identified with the difference between Greek and Jewish ethnicity.

\section{The Hellenistic and Orientalist Theses}

The question of whether a hedonistic or an ascetic mood-and hence a secular or a religious meaning-should ultimately prevail in the interpretation of Qohelet also drives the debate about its proper cultural context. To put the matter in Straussian opposition, the "joy of life" option appears linked to Athens, while the "fear of God" alternative is associated with Jerusalem.

Since the Enlightenment period, Qohelet's readers have employed considerable bilingual erudition in order to prove that the book owes its linguistic and intellectual singularities to Greek language, literature, and philosophy. Preceded in this endeavour by Harry Ranston (1925), ${ }^{21}$ in 1973, Rainer Braun published what is still the most extensive collection of textual parallels which allegedly prove that there were Greek influences on many features of the book's phraseology, worldview, and general mood. ${ }^{22}$ Braun's observations on these parallel motifs were largely accepted and frequently reissued, ${ }^{23}$ but scholars have not yet reached any consensus about them. ${ }^{24}$

Parallels with expressions from archaic and classical works such as those of Homer, Hesiod, Theognis, Sophocles, and Euripides may suggest an acquaintance with the Greek canon. However, Braun's key observation is that the philosophical

20 James A. Loader, Polar Structures in the Book of Qohelet (Berlin: De Gruyter, 1979); Jimyung Kim, Reanimating Qohelet's Contradictory Voices: Studies of Open-Ended Discourse on Wisdom in Ecclesiastes (Leiden: Brill, 2018).

21 Harry Ranston, Ecclesiastes and the Early Greek Wisdom Literature (London: Epworth Press, 1925).

22 Rainer Braun, Kohelet und die frühhellenistische Popularphilosophie (Berlin: De Gruyter, 1973).

23 A sample of the most convincing observations appears in studies such as Otto Kaiser, Der Mensch unter dem Schicksal: Studien zur Geschichte, Theologie und Gegenwartsbedeutung der Weisheit (Berlin: De Gruyter, 1985), 138-39, and Leo G. Perdue, The Sword and the Stylus: An Introduction to Wisdom in the Age of Empires (Grand Rapids, MI: Eerdmans, 2008), 234-36.

24 Reinhold Bohlen, "Kohelet im Kontext hellenistischer Kultur," in Das Buch Kohelet, 249-73, here 255 . 
topoi that spread in the Levant during the Hellenistic period did not derive from the systems of the Athenian schools, but rather represented a popularised form of sceptical thought-that is, Pyrrhonian, Cynic, and Epicurean inspiration. ${ }^{25}$ These minor genres of philosophical thought were not propagated through formal study, but as gnomic sayings in both oral and written transmission. Sextus Empiricus later affirmed that the Sceptics-just like the Cynics before them-would boil their arguments down into certain philosophical "slogans" ( $\phi \omega v \alpha$ '́). In this provocative simplification, their ideas could reach an audience that aspired to a philosophical worldview, but despised bookish culture or was excluded from it.

An example of such a "slogan" is the key phrase in Qoh 1:2, הַכּל הֶָבר , literally meaning "it is all vapour." This expression, translated as "all is vanity” (KJV), "everything is meaningless" (NIV), and "nothing matters" (CJB), has an exact parallel

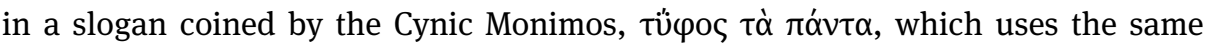
metaphor to refer to the same horizon of meaning. ${ }^{26}$ The famous sentence that fol-

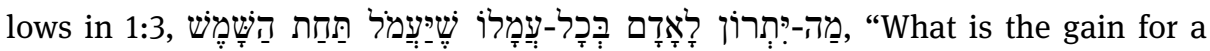
man from all the labour that he performs under the sun?", is also thought to have a Greek semantic resonance. The expression "there is no gain" mirrors the Homeric

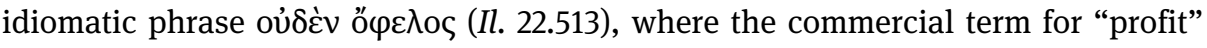
is used as a metaphor with an existential meaning. The same is true for the term

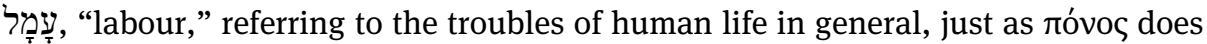
in Greek mythology, tragedy, and the speeches of the Cynics. ${ }^{27}$ "Under the sun," meaning "on earth," is another Homeric expression (Od. 4.539-40). The example shows how Qohelet's author recomposed Greek phrases and ideas in his own particular way. It has been noted that his ethics of pleasure is close to that of the Epicureans, although his pessimism does not converge with the serenity of this school. ${ }^{28}$ Rudman argued that the author was exposed to the determinism of the Stoic school, but that he was certainly not a Stoic himself, ${ }^{29}$ and a similar conclusion regarding his scepticism was reached by Stuart Weeks. ${ }^{30}$ It has also been remarked that the Cyrenaic philosophical school, with its close connection between pessimism, scepticism, and hedonism, may be the Hellenistic tradition that is closest to Qohelet's thought. ${ }^{31}$

25 Norbert Lohfink, Kohelet (Würzburg: Echter, 1980), 9.

26 Braun, Kohelet, 45-46.

27 Braun, 48-49.

28 Emmanuel Podechard, L’Ecclésiaste (Paris: Lecoffre, 1912), 95-102; Dominic Rudman, Determinism in the Book of Ecclesiastes (Sheffield: Sheffield Academic Press, 2000), 28.

29 Rudman, Determinism, 199.

30 Stuart Weeks, Ecclesiastes and Scepticism (New York: T\&T Clark International, 2012).

31 Rudman, Determinism, 28-29. On the combination of pessimism and scepticism, see also Mark R. Sneed, The Politics of Pessimism in Ecclesiastes: A Social-Science Perspective (Atlanta: Society of Biblical Literature, 2012), 7. 
These textual borrowings, it seems, do not indicate a precise doctrinal affiliation, but rather a deeper intellectual affinity, which Martin Hengel attempted to characterise in his extensive study of Greco-Jewish cultural interaction. ${ }^{32}$ Both Hengel and Braun first point to the autonomous subjectivity of the disillusioned sage, who subverts the traditional notions of religion and ethics through his reasoned argument and individual observation ("I saw"). ${ }^{33}$ Individual judgment is not a criterion of truth in earlier biblical literature, where legitimacy is sought in prophecy or in the verdict of sacred texts. Even Ben Sira, the author of Ecclesiasticus, belongs to a more nomistic intellectual climate than the author of Qohelet. ${ }^{34}$

Qohelet's individualism is not only speculative, but practical as well. The author praises a personal eudaimonía disconnected from social or political values. ${ }^{35}$ This happiness is, as it is among the Sceptics, the fruit of a radically disillusioned attitude, which rejects unattainable goals, including the purposeful pursuit of happiness itself. He confesses that his active search for pleasure as a means to perfection led him to despair (2:1-11), but that he attained happiness the moment he gave up his futile search and passively accepted pleasure as a gift from God, not as a reward for some achievement (2:24-26). ${ }^{36}$ To illustrate their similarly contradictory view, the Sceptics tell an anecdote about Apelles the painter, who achieved through an unconscious gesture what he could not achieve through his art. ${ }^{37}$

In the Hellenists' reading, even this paradoxical turn underscores Qohelet's "Greek" worldview, which is manifest in the independent quest for knowledge and happiness, as well as in the fatidic character of divine power. In Otto Kaiser's view, the belief in fate thoroughly banalises the author's final call to fear God. As a deus absconditus, God does not reward or punish humans for their actions; He only negatively limits their scope of happiness and can therefore inspire no confidence, only fear. ${ }^{38}$

As a reaction to the Hellenistic thesis, which sees the thrust of Qohelet's scepticism mainly in the attack on the belief in a personal and just God, a group of scholars inserted Qohelet into a sceptical tradition of "Oriental” coinage that turns its doubt mainly, if not exclusively, against human autonomy. Qohelet is "not Greek, but Oriental," as the Finnish Lutheran bishop Aarre Lauha put it. ${ }^{39}$ This may mean

32 Martin Hengel, Judaism and Hellenism: Studies in Their Encounter in Palestine during the Early Hellenistic Period, trans. John Bowden (Eugene, OR: Wipf and Stock, 1974), i:115-30.

33 Ludger Schwienhorst-Schönberger, "Nicht im Menschen gründet das Glück” (Koh. 2,24): Kohelet im Spannungsfeld jüdischer Weisheit und hellenistischer Philosophie, 2nd ed. (Freiburg: Heder, 1996), 237.

34 Kaiser, Der Mensch, 122-23.

35 Schwienhorst-Schönberger, "Nicht im Menschen," 253-73.

36 Schwienhorst-Schönberger, 296, 311.

37 Sextus Empiricus, Pyr. 1.28 .

38 Kaiser, Der Mensch, 128.

39 Aarre Lauha, Kohelet (Neukirchen-Vluyn: Neukirchener Verlag, 1978). 
for some that there is no demonstrable trace of Greek philosophy in his book; ${ }^{40}$ others-such as Guttmann-have held that occasional borrowings were not relevant to the author's spirit, and a third position argues that the author consciously defends Middle Eastern traditions. In any case, Qohelet's line of thinking is believed to be part of a tradition of doubt and inquiry that, anterior to Greek scepticism, derives its inspiration from pessimistic tendencies in the Oriental literatures of the early second millennium BCE. According to the Orientalists, Qohelet's conjunction between a pessimistic outlook on life and the call to partake of whatever can be enjoyed goes back to such texts as the speech of the alewife Siduri in the Old Babylonian epic of Gilgamesh ${ }^{41}$ or the Egyptian "Harpist's Songs." ${ }^{42}$ The intertextual relations are less precise in these cases and mainly consist of shared commonplaces, some of them being of a fairly general character. Their comparisons are taken from writings from various millennia, and this long-term chronology not only makes any historical contextualisation impossible, but also obliges one to operate with the dubious assumption of a timeless Oriental wisdom tradition in which a corpus of motifs could be transmitted unchanged across the ages. ${ }^{43}$ Moreover, pessimism means something quite different in the Gilgamesh epic and the Egyptian songs, where the joy of life is always recommended in the face of inescapable death and a gloomy afterworld. The doubts about virtue, knowledge, and providence that create the distress presented in Qohelet have no parallel in this literature.

Qohelet's gnomic form of expression is not, according to the Orientalists, due to the influence of the Greek Cynics or Sceptics; rather, it is due to the author's continuation of an age-old "wisdom literature" with its ancient genre of proverbs (Eccl 12:9) ${ }^{44}$ and its great themes such as providential history, ${ }^{45}$ human knowledge, ${ }^{46}$ and, as mentioned above, theodicy. In sum, while the Hellenists credit scepticism for the turn to an anthropocentric model of knowledge, the Orientalists link Qohelet to an "old Levantine" tradition of scepticism, which insists upon the supremacy of divine forces over human ones.

40 Menachem Fisch, "Ecclesiastes (Qohelet) in Context: A Study of Wisdom as Constructive Skepticism," in Critical Rationalism: The Social Sciences and the Humanities. Essays for Joseph Agassi, Volume 2, ed. Ian C. Jarvie and Nathaniel Laor (Dordrecht: Kluwer Academic Publishers, 1995), 167-87.

41 Oswald Loretz, Qohelet und der Alte Orient: Untersuchungen zu Stil und theologischer Thematik des Buches Qohelet (Freiburg: Herder, 1964).

42 Stefan Fischer, Die Aufforderung zur Lebensfreude im Buch Kohelet und seine Rezeption der ägyptischen Harfnerlieder (Frankfurt am Main: Peter Lang, 1999).

43 See the criticism in Schwienhorst-Schönberger, "Kohelet," 25-26.

44 Christian Klein, Kohelet und die Weisheit Israels: Eine formgeschichtliche Studie (Stuttgart: Kohlhammer, 1994).

45 John F. Priest, "Humanism, Skepticism, and Pessimism in Israel," Journal of the American Academy of Religion 36, no. 4 (1968): 311-26, here 323-24.

46 Annette Schellenberg, Erkenntnis als Problem: Qohelet und die alttestamentliche Diskussion um das menschliche Erkennen (Göttingen: Vandenhoeck \& Ruprecht, 2002). 


\section{The Structure of the Book}

Even the debate between literary historians backing either the Hellenistic or the Orientalist thesis centres on the question of the respective authority of the book's two moral maxims, the "joy of life" of the main part of the book and the "fear of God" of its last chapter. Do we have to give a preference to one of the two maxims, or can they be harmonised on an equal footing? The answer depends largely on the structural patterns that one discovers in the book. The majority of the critics presume that Qohelet is a planless collection of aphorisms, while the minority proposes a merely associative succession of themes held together by keywords and key phrases. Individual scholars have tried to prove the existence of a sophisticated plan: the suggestions most discussed are Addison Wright's numerological hypothesis and Norbert Lohfink's chiastic model, according to which Qohelet's argument moves back and forth between sections devoted to such anachronistic themes as "social criticism" and "ideology criticism." 47

One comparatively solid thesis, however, has put forward a structural analysis on purely formal grounds, focusing on periodically reappearing leitmotifs, especially the exhortation to enjoy sensual pleasures always designated by words derived from the root שמח. Since 1904, when John F. Genung referred to these exhortations as "landing-stages of inference or counsel," 48 exegetical tradition has commonly counted seven such passages (Eccl 2:24-26; 3:12-13; 3:22; 5:17-19; 8:15; 9:7-10; 11:710) and has convincingly argued them to be structuring devices. I would add three more such exhortations $(4: 6 ; 7: 10-14 ; 10: 19)$ and come to the conclusion that Qohelet is divided into ten parts, each one starting with a claim to experience ("I saw" and similar formulas) and ending on one of the ten commendations of pleasure. The first of the ten sections is the author's autobiography, forming an introduction to his wisdom, and if we examine the content of the other nine, there is a rough thematic partition between speculative and practical subjects that recalls the guiding idea of the Aristotelian division of the sciences, with the science of knowledge, originally called "analytics" and later called "logic," being counted among the practical sciences. ${ }^{49}$ The shift from natural cycles to the afterlife and divine judgment in chapter 3 recalls the common epistemic succession of physics followed by metaphysics (or, in Aristotle's terms, "theology”), and the same is true for the shift from politics to economics at the end. We can imagine the model of the book as a sweep-

47 Lohfink, Kohelet, 10.

48 John Franklin Genung, Ecclesiastes: Words of Koheleth, Son of David, King in Jerusalem; Translated Anew, Divided According to Their Logical Cleavage, and Accompanied with a Study of Their Literary and Spiritual Values and a Running Commentary (Boston, MA: Houghton, Mifflin, and Company, 1904), 183-84, until Martin Alfred Klopfenstein, “Kohelet und die Freude am Dasein,” Theologische Zeitschrift 47 (1991): 97-107.

49 Arist. Metaph. 6.1.5, $1025 \mathrm{~b} 26$. 


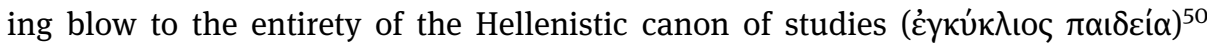
following a sceptical literary genre of which books 7-11 of Sextus's Adversus mathematicos may still give us an idea. If we tentatively identify the Greek equivalents to the subjects of Qohelet's wisdom, the overall structure of the book looks like this:

\section{1:1-12: Preliminaries}

- 1:1: first title, which identifies the author as King Solomon

- 1:2-11: prologue with a summary of the book's teachings

- 1:12: second title, again affirming the royal dignity of the author

1:13-2:26: Introduction detailing the author's experience of the pursuit of happiness,

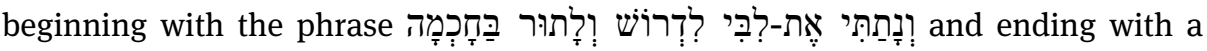
hedonistic exhortation; this part is structured in four sections:

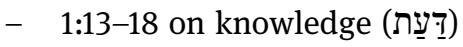

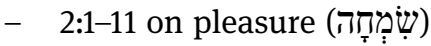

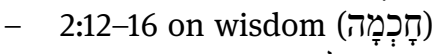

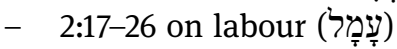

Chapters 3-11: Main part structured in nine sections on different sciences, all of them ending with a hedonistic exhortation:

- 3:1-12 on physics: everything is governed by time and fortune. This section has no introductory formula, but רִִִ ("I saw") is present in the text.

- 3:14-21 on metaphysics: both humans and beasts have the same end. Incipit:

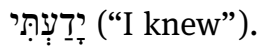

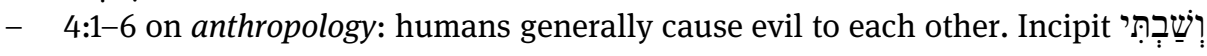

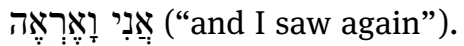

- 4:7-5:19 on psychology: humans have no control over their suffering and joy.

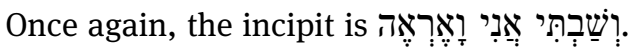

- 6:1-7:14 on history: we have no foreknowledge of life except that it will finally be erased by oblivion. Incipit: רָאִ ("I saw”).

- 7:15-8:15 on ethics: there is no righteousness and no reward for virtue. Once again, the incipit is רִִִית ("I saw").

- 8:16-9:10 on analytics: there is no knowledge of anything. The incipit is similar

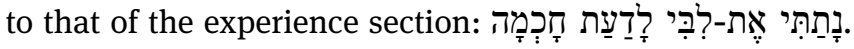

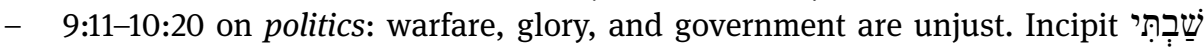
וְרָאוּ

- 11:1-10 on economics: the maxims of commercial prudence are paradoxes. This last section, like the first, opens without an introduction.

50 This term, attested from ca. 50 BCE, came to designate an educational practice whose content and structure remained remarkably stable from the third century BCE to the seventh century CE, according to Teresa Morgan, Literate Education in the Hellenistic and Roman Worlds (Cambridge: Cambridge University Press, 1998), 42. 
12:1-8: Conclusion recommending piety

12:9-14: Epilogues

- 12:9-12: First epilogue: Wisdom epilogue

- 12:13-14: Second epilogue: Piety epilogue

The very order of Qohelet's "public teaching of knowledge" (12:9) seems to result in a strong polemical challenge to the truth claims of Greek science. On the other hand, if we assume that all the hedonistic passages conclude basic structural units of the text, we are much closer to a coherent discourse focusing on pleasure than we are to a controversial dialogue in which all these hedonistic passages belong to the discourse of a sceptic and are later refuted by a God-fearer.

\section{Author and Date}

One of the major harmonising devices found in Qohelet in its present form is the attribution of the book to King Solomon, the builder of the Jerusalem Temple. This attribution is found only in two title verses $(1: 1,1: 12)$, which closely resemble the stereotypical formula by which Proverbs (1:1), Canticles (1:1), and two Psalms (72:1; 127:1) attribute later compositions to the same prestigious author. The attribution of wisdom literature to monarchs was a legitimation strategy employed to equate the hierarchies of knowledge with those of the social order, and the midrash still places a great deal of emphasis on the author's supposed royal background..$^{51}$

While linguistic analysis of the text of Qohelet has made the traditional attribution implausible, most modern scholars see two possible means of rescuing the fusion of knowledge and power: first, although Qohelet may not have been written by a king, the author presumably belonged to an elite circle of courtly councillors, temple scribes, or other tenured intellectuals, and second, his text develops a literary fiction of kingship, and if the book is not by King Solomon, it is at least about him. As the Jewish Encyclopedia cautiously writes regarding this king, "it seems to be probable that his life formed the basis of the Book of Ecclesiastes, and possibly of some elements of the Song of Songs." 52 This is specifically referring to Qohelet's literary autobiography in chapter 2 , which a widespread scholarly convention has called the "Royal Experiment." 53

51 David Kimhi on 1Kgs 11:41; see also Reuven Kiperwasser, "The Midrashim on Kohelet: Studies in their Formation and Redaction" [Hebrew]. (PhD diss., Bar-Ilan University, 2005).

52 Ira Maurice Price, Emil G. Hirsch, Wilhelm Bacher, M. Seligsohn, Mary W. Montgomery, and Crawford Howell Toy, "Solomon," in Jewish Encyclopedia, Volume 11, ed. Isidore Singer et al. (New York and London: Funk and Wagnells, 1905), 436-48, here 438.

53 James L. Crenshaw, Ecclesiastes: A Commentary (London: SCM Press, 1988), 68; R. N. Whybray, Ecclesiastes (Grand Rapids, MI: Eerdmans, 1989), 34; Y. V. Koh, Royal Autobiography in the Book of Qoheleth (Berlin: De Gruyter, 2006). 
While the scholarly consensus seems to back one of the two above-mentioned "alternatives to the original attribution, these constructs have no firm basis in the text. As Qohelet clearly states, the author of the aphorisms was a hakam (12:9), and his references to kingship deliberately assume the point of view of the subject, who disagrees with the way in which vile and incapable people obtain public office (3:16; $4: 13 ; 10: 5-6)$ and yet fears to criticise the king for such political abuses (8:2; 10:20). Not even the allegedly "royal" experiment with the pursuit of happiness gives any internal evidence regarding the author's royal identity. Aside from wisdom and labour, the author only enumerates such material means that were available to any wealthy individual: wine-drinking, residences, vineyards, gardens, orchards, ${ }^{54}$ irrigation pools, slaves, cattle, sheep, gold, silver, and entertainers. The last element

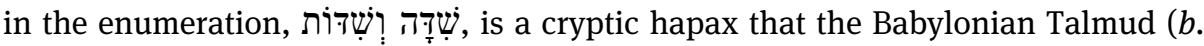
Git. 68a) explained as referring to male and female demons, Rashi to carriages, and still others to sportive games, while Abraham ibn Ezra postulated a reference to concubines simply because he expected the list to contain a mention of Solomon's many women and sexual infatuations. ${ }^{55}$ Qohelet, however, is a monogamous misogynist $(7: 26 ; 9: 9)$, and his literary self-portrait lacks indeed any decipherable reference to Solomon's emblematic harem. He likewise glosses over the latter's temple and stables: he boasts of his cows and sheep, but never mentions horses. More revealingly still, his "experiment” does not contain any mention of political justice, monumental constructions, public piety, military glory, or anything that would have pertained to a king's individual achievements. It therefore seems safe to conclude that the politics of canonisation attributed to King Solomon a book whose author was never meant to be a king, nor was he a member of a wisdom circle at court. He does not speak like a man who lives off his wisdom, but like an independent proprietor and merchant (see 11:1) who, in the Greek style, used his prosperity to fund, among other prestigious occupations, his search for wisdom (7:11-12). Some of his more interpretable statements-that he accumulated more wisdom and wealth than any Jerusalemite before him $(1: 16 ; 2: 7.9)$, that he received money from kings and faraway provinces (2:8), and that he mused about the effects of dynastic succession (2:12) -were probably not initially meant as a means of claiming royal dignity, though they would retroactively become proof of the tradition of Solomonic authorship.

The exuberant delights accumulated during the "experiment" thus portray a lifestyle that is patrician without any distinctively royal features. The frugal pleas-

54 Of all the items mentioned in the list, the garden has been claimed as a proof of royal privilege; see Arian Verheij, "Paradise Retried: On Qohelet 2.4-6," Journal for the Study of the Old Testament 16, no. 50 (1991): 113-15. However, wealthy individuals also practised horticulture, and philosophers such as Theophrastus and Epicurus were known for their gardens. See Louise Cilliers and François Pieter Retief, "Horticulture in Antiquity, with Emphasis on the Graeco-Roman Era," Akroterion 54 (2009): 1-10, here 5.

55 Mordecai b. Solomon Plungian, Kerem li-Shelomoh (Vilnius: R. M. Romm, 1857), 34. 
ures that are subsequently praised in the ten exhortations are even more at variance with the alleged courtly setting. The reader is advised to enjoy ordinary life, which consists of food and drink (2:24; 3:13; 5:17; 8:15; 9:7; 10:19), work (3:22), rest (4:6), friends (4:9), property (5:18), cleanliness and body care (9:8), conjugal intimacy (9:9), ready money (10:19), the sight of sunlight (11:7), and all stages of the lifecycle (11:9). In sharp contrast to the ambitious hedonism of the initial autobiography, the book concludes on an Epicurean ethics of the golden mean, aurea mediocritas, ${ }^{56}$ which is ideally located in a moderately affluent private home.

If Qohelet's author was an educated parvenu and not a king or a councillor, where does he fall in the history of the Levant and, more particularly, that of Jerusalem? While the Orientalists tend to favour an earlier dating, the Hellenists mostly agree that the author lived in the third century BCE under Ptolemaic rule, when Judean society had reached the levels of luxury and social inequality that the text seems to presuppose. ${ }^{57}$ The foremost representatives of Qohelet scholarship in the twenty-first century have taken this dating for granted. ${ }^{58}$ Only a few historians have placed Qohelet at a later date, after the Seleucid takeover in 198 BCE. Joseph Klausner famously attributed the book to the Tobiad warlord Hyrcanus who committed suicide in 175 BCE when King Antiochus IV rose to power, another hypothesis which is based on the allegedly royal or princely character of the "experiment." 59 Whitley claims that the book was written around 150 BCE under the latter king, who promoted Epicureanism as his state doctrine. ${ }^{60}$

The almost complete consensus in favour of dating Qohelet to the Ptolemaic period is based on simple but rather weak arguments. ${ }^{61}$ First, there is an implicit bias against the second century, which is considered to be a time of religious turmoil because of the Maccabean revolt that began in $167 \mathrm{BCE}$, and second, there is the

56 Ludger Schwienhorst-Schönberger, "Via Media: Koh 7,15-18 und die griechisch-hellenistische Philosophie," in Qohelet in the Context of Wisdom, ed. Antoon Schoors (Leuven: Leuven University Press, 1998), 181-203.

57 According to Elias Bickerman, he is "a product of Ptolemaic Jerusalem"; see Elias Bickerman, "Koheleth (Ecclesiastes) or the Philosophy of an Acquisitive Society," in Elias Bickerman, Four Strange Books of the Bible: Jonah, Daniel, Koheleth, Esther (New York: Schocken Books, 1967), 13967, here 141; Bohlen, "Kohelet," 261: "Es sind exakt die Ungerechtigkeiten des Systems, deren Kohelet sich bewußt wird."

58 Rudman, Determinism, 13; Perdue, The Sword and the Stylus, 198-255; Sneed, The Politics of Pessimism, 85-124; Lavoie, "Où en sont les études," (2019) 43.

59 Joseph Klausner, "Mehabbero shel Sefer Qohelet," Ha-Shiloah 42 (1927): 46-57. The thesis has even found its way into popular publications such as Martin Sicker, Kohelet: The Reflections of a Judean Prince. A New Translation and Commentary (New York: iUniverse, Inc., 2006). It is all the more surprising that JiSeong James Kwon and Matthias Brütsch fail to mention their predecessors when citing it in "Gemeinsame intellektuelle Hintergründe in Kohelet und in der Familientradition der Tobiaden," Zeitschrift für die alttestamentliche Wissenschaft 130, no. 2 (2018): 235-51.

60 Whitley, Kohelet, 182.

61 I follow their enumeration in Whybray, Ecclesiastes, 19-20. 
thesis that Jesus ben Sira knew the Book of Qohelet and that the latter must therefore have been written before Ben Sira's presumed composition, Ecclesiasticus, which is dated to around 180 BCE. ${ }^{62}$ However, the parallels between the two books can be explained either way. ${ }^{63}$ Finally, the complaints about the gains of the rich and the exploitation of the poor allegedly fit nicely with a date somewhere during the Ptolemaic Empire, which was known for its exorbitant taxation system-although this monarchy certainly did not have a monopoly on this economic ill.

Thus, none of the chronological arguments is particularly conclusive. On the contrary, it seems to me that the Ptolemaic dating overestimates the economic and intellectual vitality of Jerusalem in the third century BCE. Archaeological excavation shows that the temple city was a minor townlet confined to the eastern slope of present-day Silwan Hill. It was only the change of government in 198 BCE that brought about a remarkable period of urban growth. ${ }^{64}$

Wine is the most frequently mentioned consumer item in Qohelet's hedonistic exhortations $(2: 3 ; 9: 7 ; 10: 19)$. If, like Sneed, we attempt to trace wealth and luxury via the spread of wine connoisseurship, which in turn is quantifiable through the archaeological finds of the stamped handles of jars containing high-quality wine from the islands of Rhodes, Cos, and Chios, ${ }^{65}$ we must seriously reflect on the chronology of these imports that the digs in the City of David have revealed. The number of stamped jar handles from Ptolemaic times that were found in the excavations is below five per lustrum; it rises constantly for finds of handles dating to the early Seleucid period, crossing the mark of twenty around 190 BCE and then peaking above sixty during the years 175 to 167 BCE. After the rebellion, wine imports plummet, and by the fall of the Seleucid garrison in 141 BCE, they have disappeared entirely. ${ }^{66}$

In sum, the material evidence regarding the consumption of fine wines in Jerusalem allows us to make a case for dating Qohelet to the early years of King Antio-

62 According to Lohfink, Qohelet, 7, "setzt das Buch Jesus Sirach das Buch Koh voraus."

63 Rudman, Determinism, 31: "The precise relationship between Ben Sira and Ecclesiastes remains unclear."

64 Oded Lipschits, "Jerusalem between Two Periods of Greatness: The Size and Status of the City in the Babylonian, Persian and Early Hellenistic Periods," in Judah between East and West: The Transition from Persian to Greek Rule (ca. 400-200 BCE), ed. Lester L. Grabbe and Oded Lipschits (London: T\&T Clark International, 2011), 163-75. On the causes of urban growth after 198 BCE, see G. G. Aperghis, "Jewish Subjects and Seleukid Kings: A Case Study of Economic Interaction," in The Economies of Hellenistic Societies, Third to First Centuries BC, ed. Zosia Archibald, John K. Davies, and Vincent Gabrielsen (Oxford: Oxford University Press, 2011), 19-41, here 36.

65 Sneed, The Politics of Pessimism, 99.

66 Gérald Finkielsztejn, "Du bon usage des amphores hellénistiques en contextes archéologiques," in Céramiques hellénistiques et romaines: Productions et diffusion en Méditerranée orientale (Chypre, Égypte et côte syro-palestinienne), ed. Francine Blondé, Pascale Ballet, and Jean-François Salles (Lyon: Maison de l'Orient et de la Méditerranée-Jean Pouilloux, 2002), 227-33. On the sources and interpretation of the data, see also Jodi Magness, Stone and Dung, Oil and Spit: Jewish Daily Life in the Time of Jesus (Grand Rapids, MI: Eerdmans, 2011), 214-15. 
chus's reign, which was the high tide of Hellenisation in Jerusalem. There may be another basis for such a hypothesis. I am referring to a historical allusion in Qoh 4:13-15, which scholars have most frequently judged to be an assemblage of proverbial or prototypical topoi, ${ }^{67}$ but which deserves to be read in search of Qohelet's concrete political context.

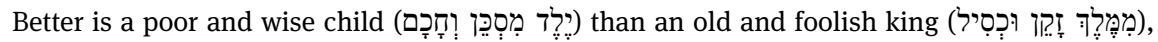

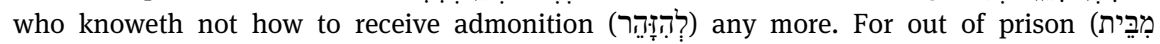
הָסוּרִים all the living that walk under the sun, that they were with the child, the second, that was to

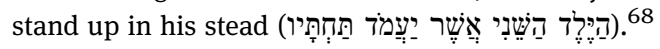

The detail of the king's past imprisonment is certainly not a proverbial topos. If we look for a historical model of this dynastic conundrum among three Hellenistic contenders, with one being qualified as old and the two others as minors, the allusions seem to fit the conditions in 175 to 170 BCE. ${ }^{69}$ Indeed, Antiochus IV Epiphanes was the only Hellenistic king who ever ascended his throne after being held captive. As a younger brother of the ruling King Seleucus IV, he was held hostage in Rome for a decade, from 188 to 178 BCE, after which time he was exchanged for Seleucus's young son and heir, Demetrius I Soter, whom the Romans would hold captive until 164 BCE. Seleucus was assassinated by the usurper Heliodorus in 175 BCE and Antiochus, now released, in turn ousted Heliodorus by force. Though he was not the dynastic successor, Antiochus ruled the Seleucid kingdom from 175 BCE together with a second nephew, Demetrius's brother, also named Antiochus, who was assassinated on his orders in 170 BCE.

With his allusion to the Seleucid succession conflict, Qohelet's author seems to have been expressing his support of the legitimate heirs, the two child-age brothers, against their uncle Antiochus. The latter was seen as an eccentric character by his contemporaries, who turned his honorific Epiphanes ("[God] manifest”) into Epimanes ("madman"), as attested by Polybius. ${ }^{70}$ When he became king in 175 BCE, he was in his forties, whereas the captive Demetrius was ten years old and his brother,

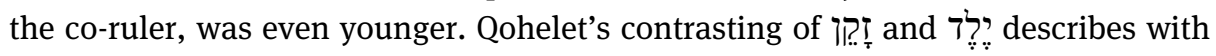
only a little exaggeration the age difference between King Antiochus and the two princes.

\footnotetext{
67 Lohfink, Kohelet, 39: "Sprichwörter”; Ze'ev Weisman, "Elements of Political Satire in Koheleth 4,13-16; 9,13-16," Zeitschrift für die alttestamentliche Wissenschaft 111, no. 4 (1999): 547-60, here 547: “a common typological pattern”; Sneed, The Politics of Pessimism, 128: "popular pseudo-history [...] prototypical picture."

68 Qoh 4:13-15; my translation is based on the American Standard Version.

69 For the following, see John D. Grainger, A Seleukid Prosopography and Gazetteer (Leiden: Brill, 1997), 37, 52.

70 Polybius, Histories 26.10.
} 
Rulers of different ages are again compared in Qoh 10:16-17, albeit in an inverted order of preference. This time, the author seems to juxtapose the two Hellenistic empires, Ptolemaic Egypt and Seleucid Syria:

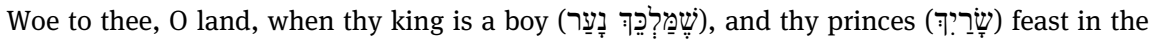

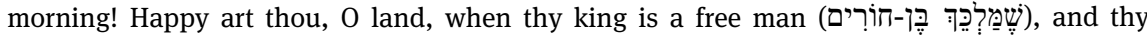
princes eat in due season, in strength, and not in drunkenness!

While King Antiochus was an adult in 175 BCE, the Ptolemaic ruler Ptolemy VI was only eleven years old, and the state was governed by his sister-wife Cleopatra II and two regents. ${ }^{71}$ Qohelet's author leaves no doubt about where his loyalties lay between the two kingdoms, which had become antagonistic by 172 BCE leading to open war two years later. Our dating of the text to the years 175 to 170 BCE places the author within a period during which the Hellenising tendencies were strongest among the Jews, creating a dynamic of economic growth from which the priestly and urban elite particularly profited. When Antiochus IV became king, he gave Jason, the son of Simon II (Simon the Just), the dignity of Jewish high priest. Jason offered to change the Jerusalem constitution in order to permit the foundation of a Greek-style polis with cultural innovations such as the opening of a gymnasium destined to educate young people. In 172 BCE, Jason was ousted by his brother Menelaus and had to flee to the Transjordan, ${ }^{72}$ while relations between Greeks and Jews became more conflicted. In retrospect, Victor Tcherikover calls Jason's time as high priest (175/4-172/1 BCE) "the rule of the moderate Hellenizers"73 and a time of prosperity during which the new constitution had no effect on religious life. ${ }^{74}$ If, as I propose, we date Qohelet to that period, then he must have witnessed a moment of important social change brought about by cultural imperialism and by the successful adaptation of an affluent colonised elite.

\section{Conclusion}

The Cynics, Epicureans, and Pyrrhonian Sceptics seem to have crossed boundaries of language and ethnicity more easily than their counterparts from the more established philosophical schools. This trend dominated the Levantine school of philosophical thought, which was based in the city of Gadara (Umm Qais, Jordan) and whose most notable figure was the satirist Menippus. The only Greek philosopher quoted in rabbinic literature, Abnomos ha-Gardi, is probably identical with Oeno-

71 Günther Hölbl, A History of the Ptolemaic Empire, trans. Tina Saavedra (London: Routledge, 2001), 143-52.

72 2Macc 4:26.

73 Victor Tcherikover, Hellenistic Civilization and the Jews, trans. Shimon Applebaum, 5th printing (New York: Athenaeum, 1979), 171.

74 Tcherikover, Hellenistic Civilization, 166-67. 
maus of Gadara, a Cynic of the second century CE. ${ }^{75}$ The epithet "Epicurean" was preserved in rabbinic parlance as a term of abuse.

James A. Loader and James Crenshaw supposed that Qohelet's author was influenced by Greek models but that his arguments were directed against wisdom traditions in an internal Jewish context. As in the Book of Job, the "crisis of wisdom" leads to the pessimistic conclusion that the world is inaccessible to human knowledge and that man has no power over his life. But as we have seen, Qohelet's scepticism has a double thrust. It limits the Jewish view of history as an instrument of divine retribution, but it also raises doubts regarding Greek science's claims to explain nature, forecast history, and promote virtue. Qohelet's location in the larger context of the multilingual reception of Greek thought among the subdued nations of the Levant has already been studied from a postcolonial perspective by Christoph Uehlinger ${ }^{76}$ and Leo Perdue. ${ }^{77}$ While studies of biblical wisdom literature may have exaggerated its "internationality" as an irenic syncretism and a "sapiential koiné" of the antique eastern Mediterranean, a transcultural approach may detect the impact of an ethnic conflict and the clash of wisdom traditions. Qohelet was produced in the midst of a complex situation, in which members of the Jerusalem religious elite are believed to have profited economically as well as intellectually from the conditions of the polis privileges that came with the Hellenistic regime. Social conditions not only prompted Qohelet's author to cover his plutocracy with fatalism and pleasure ethics, as Sneed has argued, ${ }^{78}$ but also to observe a sceptical distance from the norms of both paideia and Torah.

Qohelet's reception of popular oppositional undercurrents within a hegemonic culture may be compared to the modern intellectual circles in the Global South that appropriated Western culture via its dissidents. Chinese Marxists, for example, pursued the goal of "accepting Western culture critically" in order to resist both European imperialism and local conservatism. ${ }^{79}$ Through his selective reception of the uncanonical trends from Greek philosophy, Qohelet could challenge providential theology using the means of individual doubt on the one hand and scientific certainty via references to the hidden elohim on the other. The conflict between Athens and Jerusalem was complicated rather than mirrored by the contradiction between the joy of life and the fear of God. It was further complicated by the presence of social tension and intellectual controversy in both camps. To the elements of dissident thought that he lifted from Greek scepticism, Qohelet assigned the task of brokering a balance between the two wisdoms.

75 Yehoshua Amir, "Doch ein griechischer Einfluß auf das Buch Kohelet?” in Yehoshua Amir, Studien zum antiken Judentum (Frankfurt am Main: Peter Lang, 1985), 35-50.

76 Christoph Uehlinger, "Qohelet im Horizont mesopotamischer, levantinischer und ägyptischer Weisheitsliteratur der persischen und hellenistischen Zeit,” in Das Buch Kohelet, 155-247.

77 Perdue, The Sword and the Stylus, 232.

78 Sneed, The Politics of Pessimism, 178.

79 Li Zonggui, Between Tradition and Modernity: Philosophical Reflections on the Modernization of Chinese Culture (Oxford: Chartridge Books, 2014), 226. 


\section{Bibliography}

Amir, Yehoshua. "Doch ein griechischer Einfluß auf das Buch Kohelet?” In Yehoshua Amir, Studien zum Antiken Judentum, 35-50. Frankfurt am Main: Peter Lang, 1985.

Aperghis, G.G. "Jewish Subjects and Seleukid Kings: A Case Study of Economic Interaction." In The Economies of Hellenistic Societies, Third to First Centuries BC, edited by Zosia Archibald, John K. Davies, and Vincent Gabrielsen, 19-41. Oxford: Oxford University Press, 2011.

Barthold, Lauren S. Gadamer's Dialectical Hermeneutics. Lanham, MD: Lexington Books, 2010.

Ben Israel, Menasseh. De la fragilité humaine et de l'inclination de l'homme au péché. Translated by Henry Méchoulan. Paris: Éditions du Cerf, 1996.

Bickerman, Elias Joseph. "Koheleth (Ecclesiastes) or the Philosophy of an Acquisitive Society." In Elias Joseph Bickerman, Four Strange Books of the Bible: Jonah, Daniel, Koheleth, Esther, 139-67. New York: Schocken Books, 1967.

Birnbaum, Elisabeth. "Qohelet." Reallexikon für Antike und Christentum 28 (2017): 523-36.

Bohlen, Reinhold. "Kohelet im Kontext hellenistischer Kultur." In Das Buch Kohelet: Studien zur Struktur, Geschichte, Rezeption und Theologie, edited by Ludger Schwienhorst-Schönberger, 249-73. Berlin: De Gruyter, 1997.

Braun, Rainer. Kohelet und die frühhellenistische Popularphilosophie. Berlin: De Gruyter, 1973.

Cilliers, Louise, and François Pieter Retief. "Horticulture in Antiquity, with Emphasis on the Graeco-Roman Era." Akroterion 54 (2009): 1-10.

Crenshaw, James L. Ecclesiastes: A Commentary. London: SCM Press, 1988.

Crenshaw, James L. Old Testament Wisdom: An Introduction. 3rd ed. Louisville, KY: Westminster John Knox Press, 2010.

Delitzsch, Franz Julius. Commentary on the Song of Songs and Ecclesiastes. Translated by M. G. Easton. Edinburgh: T\&T Clark, 1891.

Delitzsch, Franz Julius. "Einleitung das Buch Koheleth." In Biblischer Commentar über das Alte Testament. Vierter Theil: Poetische Bücher. Vierter Band: Hoheslied und Koheleth, 185-97. Leipzig: Dörffling und Franke, 1875.

Ellermeier, Friedrich. "Randbemerkung zur Kunst des Zitierens: Welches Buch der Bibel nannte Heinrich Heine 'das Hohelied der Skepsis'?” Zeitschrift für die alttestamentliche Wissenschaft 77, no. 1 (1965): 93-94.

Finkielsztejn, Gérald. "Du bon usage des amphores hellénistiques en contextes archéologiques." In Céramiques hellénistiques et romaines: Productions et diffusion en Méditerranée orientale (Chypre, Égypte et côte syro-palestinienne), edited by Francine Blondé, Pascale Ballet, and Jean-François Salles, 227-33. Lyon: Maison de l’Orient et de la Méditerranée-Jean Pouilloux, 2002.

Fisch, Menachem. "Ecclesiastes (Qohelet) in Context: A Study of Wisdom as Constructive Skepticism." In Critical Rationalism: The Social Sciences and the Humanities. Essays for Joseph Agassi, Volume 2, edited by Ian C. Jarvie and Nathaniel Laor, 167-87. Dordrecht: Kluwer Academic Publishers, 1995.

Fischer, Alexander A. Skepsis oder Furcht Gottes? Studien zur Komposition und Theologie des Buches Kohelet. Berlin: De Gruyter, 1997.

Fischer, Stefan. Die Aufforderung zur Lebensfreude im Buch Kohelet und seine Rezeption der ägyptischen Harfnerlieder. Frankfurt am Main: Peter Lang, 1999.

Genung, John Franklin. Ecclesiastes: Words of Koheleth, Son of David, King in Jerusalem; Translated Anew, Divided According to Their Logical Cleavage, and Accompanied with a Study of Their Literary and Spiritual Values and a Running Commentary. Boston, MA: Houghton, Mifflin, and Company, 1904.

Gordis, Robert. Kohelet-The Man and His World: A Study of Ecclesiastes. 3rd augmented ed. New York: Schocken Books, 1968. 
Grainger, John D. A Seleukid Prosopography and Gazetteer. Leiden: Brill, 1997.

Guttmann, Julius. Die Philosophie des Judentums. Munich: Ernst Reinhardt, 1933.

Ha-Meiri, Menachem. Perush 'al Sefer Mishlei. Edited by Menachem Mendel Zahav. Jerusalem: Otsar ha-Poskim, 1969.

Haupt, Paul, trans. The Book of Ecclesiastes. Baltimore: Johns Hopkins University Press, 1905.

Hengel, Martin. Judaism and Hellenism: Studies in Their Encounter in Palestine during the Early Hellenistic Period. Translated by John Bowden. 2 vols. Eugene, OR: Wipf and Stock, 2003.

Hölbl, Günther. A History of the Ptolemaic Empire. Translated by Tina Saavedra. London: Routledge, 2001.

Ibn Ezra, Abraham. Sefer Qohelet: im Perushei ibn Ezra [Hebrew]. Edited by Mordechai Shaul Goodman. Jerusalem: Mosad Ha-Rav Kook, 2012.

Kaiser, Otto. Der Mensch unter dem Schicksal: Studien zur Geschichte, Theologie und Gegenwartsbedeutung der Weisheit. Berlin: De Gruyter, 1985.

Kim, Jimyung. Reanimating Qohelet's Contradictory Voices: Studies of Open-Ended Discourse on Wisdom in Ecclesiastes. Leiden: Brill, 2018.

Kiperwasser, Reuven. "The Midrashim on Kohelet: Studies in their Formation and Redaction" [Hebrew]. PhD thesis: Bar-Ilan University, 2005.

Klausner, Joseph. “Meḥabbero shel Sefer Qohelet.” Ha-Shiloah 42 (1927): 46-57.

Klein, Christian. Kohelet und die Weisheit Israels: Eine formgeschichtliche Studie. Stuttgart: Kohlhammer, 1994.

Klopfenstein, Martin Alfred. “Kohelet und die Freude am Dasein.” Theologische Zeitschrift 47 (1991): 97-107.

Klopfenstein, Martin Alfred. “Die Skepsis des Qohelet.” Theologische Zeitschrift 28 (1972): 97109.

Koh, Y. V. Royal Autobiography in the Book of Qoheleth. Berlin: De Gruyter, 2006.

Kwon, JiSeong James, and Matthias Brütsch."Gemeinsame intellektuelle Hintergründe in Kohelet und in der Familientradition der Tobiaden." Zeitschrift für die alttestamentliche Wissenschaft 130, no. 2 (2018): 235-51.

Lauha, Aarre. Kohelet. Neukirchen-Vluyn: Neukirchener Verlag, 1978.

Lavoie, Jean-Jacques. “Où en sont les études sur le livre de Qohélet (2012-2018)?” Studies in Religion 48,1 (2019): 40-76.

Lavoie, Jean-Jacques. “Où en sont les études sur le livre de Qohélet?” Laval théologique et philosophique 69, no. 1 (2013): 951-33.

Lipschits, Oded. "Jerusalem between Two Periods of Greatness: The Size and Status of the City in the Babylonian, Persian and Early Hellenistic Periods." In Judah between East and West: The Transition from Persian to Greek Rule (ca. 400200 BCE), edited by Lester L. Grabbe and Oded Lipschits, 163-75. London: T\&T Clark International, 2011.

Loader, James A. Polar Structures in the Book of Qohelet. Berlin: De Gruyter, 1979.

Lohfink, Norbert. Kohelet. Würzburg: Echter, 1980.

Loretz, Oswald. Qohelet und der Alte Orient: Untersuchungen zu Stil und theologischer Thematik des Buches Qohelet. Freiburg: Herder, 1964.

Magness, Jodi. Stone and Dung, Oil and Spit: Jewish Daily Life in the Time of Jesus. Grand Rapids, MI: Eerdmans, 2011.

Morgan, Teresa. Literate Education in the Hellenistic and Roman Worlds. Cambridge: Cambridge University Press, 1998.

Perdue, Leo G. The Sword and the Stylus: An Introduction to Wisdom in the Age of Empires. Grand Rapids, MI: Eerdmans, 2008.

Perry, T.A. Dialogues with Kohelet: The Book of Ecclesiastes. University Park: Pennsylvania State University Press, 1993.

Plungian, Mordecai b. Solomon. Kerem li-Shelomoh. Vilnius: R. M. Romm, 1857. 
Podechard, Emmanuel. L'Ecclésiaste. Paris: Lecoffre, 1912.

Price, Ira Maurice, Emil G. Hirsch, Wilhelm Bacher, M. Seligsohn, Mary W. Montgomery, and Crawford Howell Toy. "Solomon." In Jewish Encyclopedia, Volume 11, edited by Isidore Singer et al., 436-38. New York and London: Funk and Wagnells, 1905.

Priest, John F. "Humanism, Skepticism, and Pessimism in Israel." Journal of the American Academy of Religion 36, no. 4 (1968): 311-26.

Ranston, Harry. Ecclesiastes and the Early Greek Wisdom Literature. London: Epworth Press, 1925. Rudman, Dominic. Determinism in the Book of Ecclesiastes. Sheffield: Sheffield Academic Press, 2001.

Sakal, Asher. Sefer Qohelet: Shenei panim, peshuto shel miqra mi-zeh vehashqafat hakhmei Yisra'el mi-zeh. Holon: A. Sakal, 1959.

Schellenberg, Annette. Erkenntnis als Problem: Qohelet und die alttestamentliche Diskussion um das menschliche Erkennen. Göttingen: Vandenhoeck \& Ruprecht, 2002.

Schwienhorst-Schönberger, Ludger. "Kohelet: Stand und Perspektiven der Forschung." In Das Buch Kohelet: Studien zur Struktur, Geschichte, Rezeption und Theologie, edited by Ludger Schwienhorst-Schönberger, 5-38. Berlin: De Gruyter, 1997.

Schwienhorst-Schönberger, Ludger. “Nicht im Menschen gründet das Glück” (Koh. 2,24): Kohelet im Spannungsfeld jüdischer Weisheit und hellenistischer Philosophie. Freiburg: Herder, 1996.

Schwienhorst-Schönberger, Ludger. "Via Media: Koh 7,1518 und die griechisch-hellenistische Philosophie.” In Qohelet in the Context of Wisdom, edited by Antoon Schoors, 181-203. Leuven: Leuven University Press, 1998.

Sicker, Martin. Kohelet: The Reflections of a Judean Prince. A New Translation and Commentary. New York: iUniverse, Inc., 2006.

Sneed, Mark R. The Politics of Pessimism in Ecclesiastes: A Social-Science Perspective. Atlanta: Society of Biblical Literature, 2012.

Tcherikover, Victor. Hellenistic Civilization and the Jews. Translated by Shimon Applebaum. 5th printing. New York: Athenaeum, 1979.

Uehlinger, Christoph. "Qohelet im Horizont mesopotamischer, levantinischer und ägyptischer Weisheitsliteratur der persischen und hellenistischen Zeit." In Das Buch Kohelet: Studien zur Struktur, Geschichte, Rezeption und Theologie, edited by Ludger Schwienhorst-Schönberger, 155-247. Berlin: De Gruyter, 1997.

Verheij, Arian. “Paradise Retried: On Qohelet 2.46." Journal for the Study of the Old Testament 16, no. 50 (1991): 113-15.

Weeks, Stuart. Ecclesiastes and Scepticism. New York: T\&T Clark International, 2012.

Weisman, Ze'ev. "Elements of Political Satire in Koheleth 4,1316; 9,1316." Zeitschrift für die alttestamentliche Wissenschaft 111, no. 4 (1999): 547-60.

Whitley, Charles F. Kohelet: His Language and Thought. Berlin: De Gruyter, 1979.

Whybray, R.N. Ecclesiastes. Grand Rapids, MI: Eerdmans, 1989.

Williams, Arthur Lukyn, trans. Ecclesiastes in the Revised Version with Introduction and Notes. Cambridge: Cambridge University Press, 1922.

Zonggui, Li. Between Tradition and Modernity: Philosophical Reflections on the Modernization of Chinese Culture. Oxford: Chartridge Books, 2014. 